\title{
SEMANTIC ANALYSIS ON LEXICAL RELATIONS IN PUJAKESUMA LANGUAGE
}

\section{Tien Rafida}

Universitas Islam Negeri Sumatera Utara

titinrafida@gmail.com

\begin{abstract}
Human beings need language as their communication because language as the branch of linguistic. When all people speak in a communication is a process and then, there must be both sender and receiver. Sometimes, all people only talk interaction not only directly interact and something more meaningless. In the branch of linguistics, semantic is the study about all the aspects of meaning outside the grammatical of language which different with morphology and syntax that concern with grammatical of language. In this paper, the writer interest to discuss about semantic analysis on lexical in Pujakesuma because semantics is one of the important aspect in linguistics and lexical of Javanese society nomads in Sumatera Utara (Pujakesuma) is also have different meaning to be analyzed.
\end{abstract}

Keywords:

Linguistic, Lexical Semantics, and Pujakesuma

\section{INTRODUCTION}

For linguists, and for the purposes of the field of the study of language, meaning that became the center of attention on semantic research. Then the meaning of language is studied and analyzed in some particular perspective. The meaning of a sentence is a projection of the lexical meaning of the word and the word in that sentence has lexical relation. Lexical relations are relationship of the meaning of a word to other words. They are homonymy, polysemy, synonymy, opposites (antonym), hyponymy, 
metonymy, member collection, and portion-mass. It's one of the semantic field's aspects that are researched by the researchers.

Semantics is the branch of linguistics devoted to the investigation of linguistic meaning, the interpretation of expressions in a language system (Chierchia, \& Mcconell, 1992). Chomsky (in Chaer, 2009, p.285) stated the importance of semantics in the study of linguistics, semantics studies as part of linguistic studies are becoming increasingly considered. Various theories about the meaning began to emerge. This is the illustration.

Psychologist

- Interest in how individual human learn

- How they retain, recall or loss information

$>$ Philosophies

- Concerned with how we know, how any particular fact that we know

- Accept as true was related to other possible facts

Linguistic

- Want to understand how language works

As a research object, the semantics of the Pujakesuma language still show aspect - the aspect that has not been thoroughly studied. In connection with the study of the semantics are still lacking, this research will discuss one of the branches that exist in the study of semantics, especially the local language lexical relation of Pujakesuma language in Percut Sei Tuan especially in Mr. Purnomo's family. After the first observation is done by the researchers. The local language is different in pronunciation as the vowel sound ' $a$ ' in the Pujakesuma language is pronounced as 'o' for example 'who' 
became 'sopo', five as 'limo' and keep to 'njogo'. In addition, the meaning is also closely linked or related, not only with the structure of the language itself, but also with the social culture of the language users, so any impression that the meaning of it is subjective.

Then, the problem of this study is "How is the using of lexical relation in Pujakesuma language, especially in conversation of $\mathrm{Mr}$. Purnomo's family?"

The objective of the research is to analyze the using of lexical relation in Pujakesuma language especially in conversation Mr. Purnomo's family.

This research focuses to daily conversation in Mr. Purnomo's family which is located on Jl. Cinta Rakyat Percut. Furthermore, this research also limits in lexical relations. There are many kinds of lexical relations. In this case the scope of the study is focused about homonymy (homograph), polysemy, synonymy, antonymy (opposites), and hyponymy.

This study hoped would give contribution for linguistic learners/future researchers who interested in lexical relations of semantic in Javanese language. This study also hoped will give contribution for readers in implementing this study in their daily life when they interact with others and give some supporting data from this study. It is useful when people are able to enrich their ability in mastering other languages. It gives them easiness in communicating with many different social backgrounds.

\section{Definition of Lexical Semantics}

Semantics is a branch of science that studies the meaning, either lexical meaning or grammatical meaning. Palmer stated (1981), semantics is the technical term used to refer to the study of meaning and since meaning is a part of language, semantics is a part of 
linguistics". Then, Gennaro (1992) said that semantics is the branch of linguistics devoted to the investigation of linguistic meaning, the interpretation of expressions in a language system. Therefore, object of study in semantics is the meaning of the language. More precisely, the meaning of language units such as words, phrases, clauses, sentences, and discourse. Language has a level-level analysis, i.e. phonology, morphology, and syntax. There are several types of semantics, which are distinguished based on the level or part of the learned language is the lexicon of the language, the semantic type is called lexical semantics.

Lexical semantics concerns to lexical meaning. The field that examines the lexical semantics according to its principles called lexicology. Lexical meaning can also be interpreted in accordance with the guidelines, meaning that according to the observation results of the five senses, or the meaning that is real in our lives. According to Lyons (1995) 'The noun, lexeme' is of course related to the words 'lexical and lexicon, (we can think of, lexicon' as having the same meaning as vocabulary or dictionary). In the lexical semantic meanings investigated the lexemes of a language. Therefore, the meaning of lexeme is called lexical meaning. Lexemes are terms commonly used semantics to specify a meaningful language.

\section{Lexical Meaning Relations}

Lexical relations are relationship of the meaning of a word to other words (Murphy, 2003). Then, Lyons (1977) said that meaning property is one of several features or component which together can be said to make up the meaning of a word or utterance. 
The term of lexical meaning relations is the meaning of various relationships contained in a word or lexeme. Meaning of the words forming its own pattern, the pattern of links or relations lexical semantics. Link between the tangible words are homonymy, polysemy, synonymy, opposites (antonym), hyponymy, meronymy, member collection, and portion-mass. The embodiment link of those meaning can be grouped as follows:

1. The relation between lexical form and lexical meaning which involves:

a. Synonymy : More than one form related to one meaning

b. Polysemy : The same form which has more than one meaning

2. The relation between the two meanings which involves:

a. Opposites : The position of a meaning outside of the other meaning.

b. Hyponymy : The scope of meaning in a different meanings

3. The relation between the two forms which involves:

a. Homonym : the form refers to two different referents.

b. Homophones : a sound refers to the two forms and two different referents.

All of lexical relations and meaning properties can be differentiated by looking all the words or sentences. 


\section{Types of Lexical Relations}

Saeed (1997) said that there are a number of different types of lexical relation. A particular lexeme may be simultaneously in a number of these relations, so that it may be more accurate to think of the lexicon as a network or link. The meaning of words or lexemes in a language which will form a pattern which is called link meaning. This indicates that the word or lexeme as a sign of language composed of form and meaning.

Based on Cruse (1986), the types of lexical relations are homonymy, polysemy, synonymy, opposites (antonym), hyponymy, meronymy, member collection, and portion-mass. So, in this research relationship between word meanings are homonymy, polysemy, synonymy, antonymy, hypernomy, hyponomy, and meronymy.

\section{a. Homonymy}

Homonymy lexemes that share a form but have unrelated, distinct meanings. The clear examples are:

- bat (wooden stick-like thing) versus bat (flying scary mamal thing)

- or bank (financial institution) versus bank (riverside)

Homonymy can be homophones, homographs, or both. The examples of homophones are write and right, and piece and peace. Homonymy causes problems for NLP applications. They are:

- text-to-speech

it is the same orthographic form but different phonological form. For example: bass versus bass 
- information retrieval

it is different meanings but have same orthographic form such as QUERY: bat care

- machine translation

- $\quad$ speech recognation

Homophones is the case where two words are pronounced identically but they have different written forms. They sound alike but are written differently and often have different meanings, for example "no and know", "led and lead", "would and wood", etc.

Homograph is a word which is spelled the same as another word and might be pronounced the same or differently but which has a different meanings, for example bear to bear. When homonyms are spelled the same they are homographs but not all homonyms are homographs.

\section{b. Polysemy}

Polysemy is used in semantics and lexical analysis to describe the word with multiple meanings. A well-known problem in semantics is how to decide whether we are dealing with a single polysemous word or with two or more homonyms. Both of terms have distinctions, such as:

1. Polysemy comes from one word, while homonym comes from two words or more.

2. The meaning in Polysemy still has relation with the basic meaning, while the meaning in homonym has no relation.

There are some examples of polysemy, they are: 
- The bank is constructed from red brick. I withdrew the money from the bank.

- While some banks furnish sperm only to married women, others are less restrictive.

From those examples, which sense of bank is this? Is it distinct from (homonymous with) the river bank sense? How about the savings bank sense?

\section{c. Synonymy}

Synonymy is used to mean sameness of meaning. Synonym is a word, which has the same or nearly the same meaning as another word. It is different phonological words which have similar meanings.

There are some words that have the same meaning in some or all contexts. They are: filbert/hazelnut, couch/sofa, big/large, automobile/car, vomit/ throw up, and water $/ \mathrm{H}_{2} \mathrm{O}$. Two lexemes are synonums if they can be successfully subtituted for each other in all situations. So, they have the same propositional meaning.

\section{d. Antonymy (Opposites)}

The word antonymy derives from the Greek root anti (opposite) and denotes opposition in meaning. It is useful, however, to identify several different types of relationship under a more general label of opposition.

In antonymyms, the senses that are opposites with respect to one feature of their meaning. Otherwise, they are very similar such as dark/light, short/long, hot/cold, up/down and in/out. More 
formally, antomyms can define a binary opposition or at opposite ends of a scale for examples long/short and fast/slow. and it can be reversives like rise/fall and up/down.

\section{e. Hyponym}

Hyponymy is a relationship between two words in which the meaning of one word includes the meaning of the other word. It is a relation of inclusion. It is a subordinate, specific term whose referent is included in the referent of super ordinate term, for example:

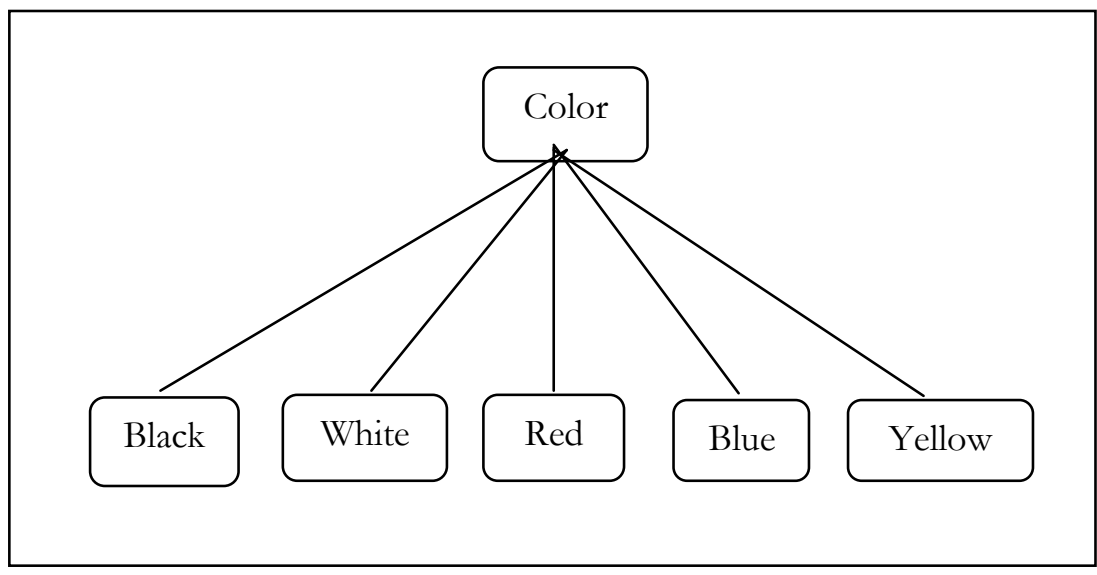

From the figure above, "black, white, red, blue and yellow" is the specific terms which is called by hyponym, while "color" is the superordinate term which is called hypernym. In a lexical field, hyponymy may exist at more than one level. A word may have both a hyponym and a super ordinate term.

\section{Pujakesuma language}

According to Wedhawati (2006), Pujakesuma language is the language of the area is still used by native speakers and language as a communication tool. It is the language used by Javanese population 
in Java. In addition, the Pujakesuma language is also used by residents who live some other areas such as Lampung, North Sumatra, Jambi, South Sumatra, and others. Especially, Java community in North Sumatra, they are the descendants of contract laborers employed in various parts of the tobacco plantations, particularly in Deli area. So it often referred as Java Deli or Pujakesuma.

In Pujakesuma language, there are lexical relations, such as polysemy, homonym, synonym, antonym, etc. For example "mangan and dhahar" show the synonym in Pujakesuma language which mean eating. Then, "apik and elek" show the antonym in Pujakesuma language which means beautiful and bad, etc. Therefore, the researchers try to find out and analyze the lexical relations in Pujakesuma language.

\section{RESEARCH METHODOLOGY}

\section{Research Design}

This study was conducted by using descriptive qualitative or content analysis research design. Bogdan and Biklen (1982) states "qualitative methodology" as the research procedures which produce descriptive data in the form of words written or spoken of people and behaviors that can be observed. Then, they also stated that a research is descriptive with the natural setting as the direct source of the data and the researcher is the key instruments. So, the data collection is very dependent on the researcher. The data are collected in the form of words in order to give more understanding the researcher does not reduce the page upon page of narration. The 
researchers analyze the data with all of the richness as closely as possible to the form.

\section{Source of Data}

According to Arikunto (2002), data source is the subject from which the data are obtained. The subject of this research is directed at the search data to the daily conversation in Mr. Purnomo's family that located in Desa Cinta Rakyat, Percut Sei Tuan. The family member consists of five persons. They are Mr. Purnomo (husband), Mrs. Purnomo (wife), Sri (the first child), Wita (the second child), Darma (the third child). All of the family members act as key informants. Determination of sampling in this case is to capture as much information from a variety of sources, which is aimed at detailing the specificity that is unique within the context of the herb. In addition, the presence of sampling is also intended to gather information that will be the basis of design and the emerging theory. Therefore, the qualitative research is no random sample but purposive sampling.

\section{Technique of Data Collection}

According to Lincoln and Guba (1984) stated collecting data in qualitative research is done directly by the researcher through observation, interviews, and assessment documentation. In this research, the researcher collect the data by following steps:

1. Observation

Observation is an effort to obtain the data. In this observation will be seen from the family member's 
conversation. Observations carried out to obtain data and information on the implementation of the plan in an effort to achieve the required standard of management education through direct observation. The results of direct observations made field notes to be prepared after holding a direct connection with the subject under study and the observed.

2. Documentation.

The documentation conducted an assessment of the documents that are considered to support the research. The researchers collect the documentation by taking some photos when observe the family member's taking the conversation, and transcription of conversation.

\section{Technique Analyzing Data}

In analyzing the data, the researchers used Padan method. It is used in determining the function and meaning of lexical. To obtain good results of data analysis performed a number of stages. The following stages are:

1. Transcribe the data from spoken into written language.

2. Translation of Pujakesuma language into Indonesian.

3. Classifying various types of lexical semantics.

4. Determining the meaning contained in the sentence.

\section{Analysis}

Lexical items are considered significant if do not change form to support and fulfill the meaning of a concept or have a references. Pujakesuma language has lexeme is mostly represented in the form of 
words in the lexicon of the Pujakesuma language. So the biggest number of lexicon element in the Pujakesuma language is a word. The following words are found by the researchers in pieces of Mr. Purnomo's family conversation:

\begin{tabular}{|c|c|c|}
\hline Kakang (n) & 'abang & /kakak laki-laki' (brother) \\
\hline mbak & (n) & 'kakak perempuan' (sister) \\
\hline pakde & (n) & 'uwak/abang dari ayah atau ibu' (uncle) \\
\hline bocah & (n) & 'anak - anak' (cbildren) \\
\hline iwak & (n) & ‘ikan’ (fish) \\
\hline mangan & (v) & 'makan" (eat) \\
\hline ngampleng & (v) & 'mukul' (beat) \\
\hline lungo & (v) & 'pergi' (go) \\
\hline jagong & (v) & 'duduk' (sit) \\
\hline ngadek (v) & 'berdit & ri '(stand) \\
\hline ndelok & (v) & 'melihat' (see) \\
\hline ngomong & (v) & 'berbicara' (speak) \\
\hline apik & (adj) & 'bagus' (good) \\
\hline ayu & (adj) & 'cantik' (beautiful) \\
\hline elek & (adj) & ‘jelek’ (ugly) \\
\hline pinter & (adj) & 'pintar' (clever) \\
\hline goblok & (adj) & 'bodoh'(stupid) \\
\hline resik & (adj) & 'bersih' (clean) \\
\hline gedi & $(\operatorname{adj})$ & 'besar' (big) \\
\hline cilik & (adj) & 'kecil '(small) \\
\hline abang & $(\operatorname{adj})$ & 'merah' (red) \\
\hline ireng & (adj) & ' hitam’ (black) \\
\hline ijo & (adj) & ' hijau' (green) \\
\hline
\end{tabular}




$\begin{array}{ll}\text { keset } & \text { (adj) 'malas' (laay) } \\ \text { siji } & \text { (num) 'satu' (one) } \\ \text { loro } & \text { (num) 'dua '(two) } \\ \text { telu } & \text { (num) 'tiga' (three) } \\ \text { papat } & \text { ( num ) 'empat' (four) } \\ \text { limo } & \text { ( num ) 'lima' (five) }\end{array}$

\section{Homonym}

In this research the researchers found the kinds of homonym. That is homograph. Homograph is words that have same in sounds and same writing as well, but pronounced with different pressures and have different meanings. In the Pujakesuma language has some words that characterized this homograph, such as:

1. Mr. Purnomo : "Aku senang tenan mangan kue gemblong iku."

Purnomo’s son : "Uwes macem gemblong iku ku delok"

"Gemblong" has different ways to pronounced but the same writing. The first, "Gemblống" means the kinds of traditional cake in Java made from sticky rice. While, the second meaning, "Gemblong" means the people who have dementia.

2. Purnomo’s wife : “Roso tenen leng kerjo".

Mr. Purnomo : "Pait tenan ku roso obat ini."

"Roso has also has different meanings if it is pronounced differently. First, "roso" means taste, while, the second "roso" means "strong". 


\section{Polysemy}

Polysemy is one word / lexeme that has more than one meaning. In the Pujakesuma language has a word that has the characteristics of this polysemy. Words that like this has the possibility to cause ambiguity in a particular sentence.

Example:

1. Purnomo’s daughter : : "iki dino mamak ku nyayur iwak

$$
\text { pari." }
$$

Purnomo's wife : : "saiki esek nandor pari."

"Par" has two meanings. First, "Par" means kinds of fish. Second, "Pari" means (rice plant)

2. Purnomo's son : "Kerno kepanasan raih ne abang."

Purnomo’s daughter : : "Mak abang uwes bali?"

"Abang" has two meanings also. First, "Abang" means red color, but in the second, "Abang" means brother.

\section{Synonyms}

Synonyms are semantic relationships that express the similarity of meaning between the units of speech with more speech units. For example, the Indonesian "buruk" and "jelek" are two synonyms. They are two words that are synonymous. The relationship between the two synonyms is two-way. So, if kembang is synonymous with bunga, bunga is also synonymous with the kembang. Lexical relations between synonyms have semantic traits are largely same. The difference between the words - these words tend to use in the context of a sentence. Javanese also have synonyms, such as: 
1. Purnomo's son : "Kue jadi uwong atos ndase."

Purnomo’s wife : "Sampeyan mau dicelok bopo mu?”

"Kue" and "sampeyan" have the same meaning. They mean subject "you".

2. Purnomo's wife : “Ayu wae kue nak rambute panjang."

Purnomo's son : "Luwes tenan cewekmu."

"Ayu" and "luwes" mean beautiful.

\section{Antonym}

Antonym is a semantic relationship between two units of speech whose meaning is stating the opposite, opposition or contrast with one another. Viewed from the relationship, can be distinguished by gradual antonyms and absolute antonyms. In the Pujakesuma language is also found words that have antonyms, which is words that have a meaning contradictory relationship. Contradictory meanings rrelationship in Pujakesuma language is absolute.

Example:

1. Purnomo's daughter : "Gedi tenan plastike"

Purnomo's wife : "Cilik tenan baju seng tes tak tuku."

"Gedi" means big and "cilik" means small. "Gedi" is antonym of "cilik".

2. Mr. Purnomo : "Jadi uwong wedok iku kudu rajin."

Mr. Purnomo : :Lanang mu wes mangan?”

"Lanang" is antonym of "wedok". "Lanang" means boy and "wedok" means girl. 


\section{Hyponym}

Hyponymy is a relationship between two words in which the meaning of one word includes the meaning of the other word. It is a relation of inclusion. It is a subordinate, specific term whose referent is included in the referent of super ordinate term, the hyponym that is found in this research, such as:

Purnomo’s wife : : "Baju warna opo seng sampeyan tuku?

Purnomo’s daughter : "ireng sama poteh".

From the conversation above "ireng" (black) and "poteh" (white) are the specific terms which is called by hyponym, while "warna" (color) is the superordinate term which is called hypernym.

\section{FINDINGS}

By analyzing the data above, the research found that in Pujakesuma language has lexeme is mostly represented in the form of words in the lexicon of the Pujakesuma language. Then, in Pujakesuma language, the researchers found not all of the types of lexical relations but some of them such as, polysemy, homograph, synonym, antonym, and hyponym.

\section{CONCLUSION AND SUGGESTION}

\section{Conclusion}

The researcher conclude that Lexical semantics concerns to lexical meaning. Lexeme is mostly represented in the form of words in the lexicon of the Pujakesuma language. Lexical relations are relationship of the meaning of a word to other words. Then, in Pujakesuma language, the researchers found not all of the types of 
lexical relations but some of them such as, polysemy, homograph, synonym, antonym, and hyponym.

\section{Suggestion}

Through this study it is suggested that the results of this study can be followed up with more efforts planned to preserve and foster the use of the Pujakesuma language. Because the language of the area is a symbol of regional identity of the owner of ethnic language and therefore it is natural language user needs to be nurtured and conserved regions in accordance with the role of the local language function. This is done in order to prevent the extinction of the local language and can strengthen the love of country and nation. Especially for people who have tribes of the same nation.

\section{REFERENCES}

Arikunto, S.(2002). Prosedur penelitian. Jakarta: Rineka Cipta.

Bogdan, R. C. \& Biklen, S. K. (1992). Qualitative research in education: An introduction to theory and methods $\left(2^{\text {nd }} e d\right)$. Boston: Prenada Media.

Gennaro, C. (1992). Meaning and grammar: An introduction to semantics. London: The MIT Press Cambridge.

Lincoln, Y.S \& Guba, E.G.(1984). Naturalistic inquiry. Beverly Hills: Calif, Sage.

Lyons, J. (1995). Linguistic semantic on introduction. Cambridge: Cambridge University Press.

Murphy, G. L. \& Medin, D. L. (1985). The role of theories in conceptual coherence. Psychological Review 92: 289-316.

Palmer, F. R. (1981). Semantics : A new outline Cambridge. Cambridge University Press. 
Saeed, J. I. (1997). Semantics. China: Blackwell Publisher. 